\title{
各科手術での使用：整形外科・形成外科手術 一区域麻酔との関連性一
}

山口重樹*

[要旨］整形外科および形成外科手術の麻酔管理においてもデスフルランの使用頻度は高い．他の 揮発性吸入麻酔薬同様にデスフルランには鎮痛効果がないため, 麻酔維持中はオピオイド鎮痛薬あ るいは局所浸潤，区域麻酔の併用が必要である. オピオイド鎮痛薬の併用は術後の嘔気・嘔吐の原 因となるため, 可能な限り局所浸潤, 区域麻酔を併用すべきである. デスフルランが推奨される場 面は, 術中・術後の神経学的評価が必要な脊椎手術, 術後認知機能障害が問題となる高齢者の大腿 骨頸部骨折手術などである. 小児では, 脊椎手術以外の整形外科手術でのデスフルランの有用性は 少ない. 日帰り手術が可能な形成外科手術においてデスフルランは有用な選択肢である.

キーワード : 運動誘発電位, 術後せん妄, 脊椎手術, 大腿骨頸部骨折, 日帰り手術

\section{はじめに}

整形外科および形成外科手術の麻酔管理において もデスフルランの使用頻度は高いはずである。しか しながら，デスフルランを用いた麻酔維持の限界， 問題点を熟知して使用しなければならない。本稿で は，デスフルランを用いた整形外科および形成外科 手術での, 局所・浸潤麻酔の重要性, デスフルラン の有用な場面, 小児における問題点等について述 ベる.

\section{Iデスフルランを用いた 整形外科・形成外科手術の麻酔管理における 局所浸潤・ 区域麻酔の重要性}

デスフルランのみならず揮発性吸入麻酔薬には十 分な鎮痛作用がないため, デスフルランでの麻酔維 持中はなんらかの鎮痛手段が必要となる。デスフル
ランを用いた整形外科および形成外科の麻酔管理で は，施行可能であれば局所浸潤あるいは区域麻酔が 有効な鎮痛手段となる。

整形外科あるいは形成外科手術では, 開腹手術と 異なり, 早期離床，早期の飲水・飲食が可能である ため，麻酔後に嘔気・嘔吐などの全身性の副作用を いかに予防するかが重要となる。そのため，鎮痛作 用を有していないデスフルランでの麻酔維持では, いかにオピオイド鎮痛薬の使用量を減じるかで，局 所浸潤あるいは区域麻酔が重要な鍵となる.

筆者は整形外科あるいは形成外科手術では，デス フルランに限らずすべての成人の全身麻酔において 施行可能な局所浸潤あるいは区域麻酔を併用して いる。

\section{II デスフルランを用いた资椎手術の麻酔管理}

脊椎手術では, 手術操作による脊髄神経損傷, 出
著者連絡先 山口重樹

干 321-0293 杤木県下都賀郡壬生町北小林 880 獨協医科大学医学部麻酔科学講座 
血による脊髄神経圧迫, 脊椎アライメントの変化に よる脊髄神経への影響などにより, 感覚異常, 運動 機能異常, 異常な痛みなどの術後合併症の恐れがあ る。そのため, 手術終了後は, 早期の覚醒, 認知機 能や運動機能の回復が望まれる。近年では, 脊椎手 術に伴う神経合併症の予防・早期発見のために運動 誘発電位 (motor evoked potential：MEP)などの神 経モニタリングが術中に行われている。また，MEP 等の代わりに患者を術中に覚醒させて神経学的評価 (wake up test)を行っている施設もある。いずれに せよ，術中・術後の神経学的評価に適した麻酔法の 選択が重要となり，デスフルランが有用な選択肢と なりえる。

デスフルランは血液/ガス分配係数, 臓器 / 血液 分配係数ともに他の揮発性吸入麻酔薬と比較して小 さく, 麻酔からの覚醒が早く, 認知機能回復が早い とされ, 術中の wake up test ${ }^{1)}$, 術後早期の神経学 的評価 ${ }^{2), 3)}$ に優れている.

春椎手術中に行われる MEP記録では, 一般的に 静脈麻酔薬が推奨されている。しかしながら, $1 \mathrm{MAC}$ 以下の低濃度のデスフルランでは MEP 記録に影響 を及ぼさないということが立証されている。そのた め, MEP記録下での脊椎手術の麻酔管理において も，デスフルランは有用な選択肢の一つである (表 1) ${ }^{4)}$.

これらの理由から，筆者は春椎手術では，プロポ フォールを用いた全静脈麻酔と同様に低濃度 (1MAC 以下)のデスフルランを用いて麻酔管理を行ってい る。その手順を下記に示す。

(1)麻酔導入はプロポフォール $(1 \sim 2 \mathrm{mg} / \mathrm{kg}) ， レ ミ$ フェンタニル $(0.2 \sim 0.5 \mu \mathrm{g} / \mathrm{kg} /$ 分 $)$, ロクロニウ ム $(0.6 \mathrm{mg} / \mathrm{kg})$ により行う。

(2)気管挿管後に新鮮ガス流量 $6 \mathrm{~L} /$ 分, $3 \%$ のデスフ ルランの吸入を開始する。レミフェンタニル $(0.2$ $\sim 0.3 \mu \mathrm{g} / \mathrm{kg} /$ 分)の持続投与は継続する.

(3)体位変換が必要な際には, 呼気ガスのデスフルラ ン濃度が安定した時点で，体位変換を行う。

\section{表1 各種麻酔薬が運動誘発電位に及ぼす影響}

\begin{tabular}{l|l|l}
\hline \multirow{5}{*}{ 吸入麻酔薬 } & $\begin{array}{l}\text { 1MAC を超えるイソフルラン, } \\
\text { セボフルラン, デスフルラン }\end{array}$ & 高度 \\
\cline { 2 - 3 } & $\begin{array}{l}\text { 1MAC以下のイソフルラン, } \\
\text { セボフルラン, デスフルラン }\end{array}$ & 中等度 \\
\cline { 2 - 3 } & 亜酸化窒素 & 中等度 \\
\hline \multirow{5}{*}{ 静脈麻酔薬 } & バルビツレート & 高度 \\
\cline { 2 - 3 } & ベンゾジアゼピン & 中等度 \\
\cline { 2 - 3 } & プロポフォール & 中等度 \\
\cline { 2 - 3 } & ケタミン & なし \\
\cline { 2 - 3 } & フェンタニル(通常量) & なし \\
\cline { 2 - 3 } & フェンタニル(高用量) & 軽度 \\
\hline
\end{tabular}

〔文献4）より引用・改変]

(4)体位変換終了後は，呼気ガスのデスフルラン濃度 が安定していることを確認してから低流量麻酔へ 移行する.

(5)手術中のデスフルラン濃度は $3 \%$ に固定し，手術 侵襲に応じて適宜レミフェンタニルの投与量 $(0.2$ $\sim 1.0 \mu \mathrm{g} / \mathrm{kg} /$ 分) を調節する.

(6) MEP 記録開始時に十分な振幅が得られない際に は，スガマデクスを用いて筋弛緩作用を拮抗す る。

(7)覚醒時の気道刺激，交感神経刺激に伴う有害事象 の予防と術後鎮痛を兼ねて，手術終了に合わせて フェンタニルの投与を開始する.フェンタニルは, 手術終了 30 分前を目安に $2 \sim 4 \mu \mathrm{g} / \mathrm{kg}$ ボーラス 静注し, 以降 $20 \sim 50 \mu \mathrm{g} / \mathrm{kg}$ で持続静注する.

8術後 X線撮影が終了, 整形外科医の確認が取れ た後に患者を仰臥位とし，この時点で新鮮ガス流 量を $6 \mathrm{~L} /$ 分とし, デスフルランの吸入を中止する. (9)呼気ガスからデスフルランが検出されなくなった 後, レミフェンタニルの持続静注を中止し, 患者 の覚醒を待って抜管する。

(10)必要に応じて，スガマデクスを投与する。

以上のような麻酔計画で，術後早期の神経学的所 見の確認, wake up test, MEPへの対応が可能と なり，脊椎手術におけるデスフルランの有用性を実 感している. 


\section{III デスフルランを用いた 高齢者大腿骨頸部骨折手術の麻酔管理}

社会の高齢化により大腿骨頸部骨折を受傷し，手 術を受ける高齢者は増加している. 高齢者の麻酔管 理の問題点の一つとして,術後せん妄があげられる. 大腿骨頸部骨折手術では，手術時間が比較的短時間 であるにもかかわらず，せん妄の発現率が高いこと が指摘されている ${ }^{5)}$. . 受傷患者が高齢者であるこ とが一つの要因である.

麻酔法によるせん妄の発症率に関する統一した見 解はないが, 血液/ガス分配係数, 臟器/血液分配 係数ともに他の揮発性吸入麻酔薬と比較して小さい デスフルランは, 術後のせん妄や認知機能の障害が 少ない可能性を示唆する報告も見られるようになっ ている7) 9)、(ずれにせよ，セボフルランやプロポ フォールと比較して劣るということを積極的に示唆 する報告はない.

筆者のデスフルランを用いた高齢者の大腿骨頸部 骨折の麻酔管理法を以下に示す。

\section{1. 区域麻酔施行例 (ラリンジアルマスク使用)}

(1)フェンタニルの少量投与 $(1 \sim 2 \mu \mathrm{g} / \mathrm{kg})$ とセボフ ルランの吸入 $(2 \sim 5 \%)$ による緩徐導入を行い, 十分な麻酔深度が得られたのちにラリンジアルマ スクを挿入する。基本的には，患者の自発呼吸を 残した状態を維持する。

(2)ラリンジアルマスク挿入後, 患者の状態が落ち着 いた時点で，新鮮ガス流量 $6 \mathrm{~L} /$ 分， $3 \%$ のデスフ ルランの吸入を開始する。

(3)呼気ガスのデスフルラン濃度が安定した後に, 低 流量麻酔へ移行する。

(4)低流量麻酔へ移行し, 呼気ガスのデスフルラン濃 度が安定した後に，区域麻酔を行う。

(5)手術中は, 区域麻酔の効果, 循環動態の変動を参 考に，デスフルラン濃度は $0.5 〜 1 \mathrm{MAC}$ に維持す る。

6 酸素化が許せば，デスフルランの気道の刺激性を
防ぐために, 覀酸化窒素, 少量のフェンタニル $(0.2$ $\sim 0.5 \mu \mathrm{g} / \mathrm{kg} /$ 回の間欠的投与)を併用する.

(7)術後 X線撮影が終了, 整形外科医の確認が取れ た後に，新鮮ガス流量を $6 \mathrm{~L} /$ 分とし，デスフルラ ンの吸入を中止する。

(8)呼気がスからデスフルランが検出されなくなった 後，西酸化窒素の投与を中止し，患者の覚醒を待 って抜管する。

(9)亜酸化窒素を併用しない症例では，覚醒時の気道 の刺激性を抑える目的で，手術終了時に少量のフ エンタニル $(0.2 \sim 0.5 \mu \mathrm{g} / \mathrm{kg} /$ 回 $)$ を投与する.

2. 区域麻酔非施行例 (気管挿管下にレミフェンタニル 使用）

(1)麻酔導入はプロポフォール $(1 \sim 1.5 \mathrm{mg} / \mathrm{kg}), レ ミ$ フェンタニル $(0.2 \sim 0.3 \mu \mathrm{g} / \mathrm{kg} /$ 分 $) ，$ ロクロニウ ム $(0.6 \mathrm{mg} / \mathrm{kg})$ により行う。

(2)気管挿管後に新鮮ガス流量 $6 \mathrm{~L} /$ 分， $3 \%$ のデスフ ルランの吸入を開始する。引き続きレミフェンタ ニル $(0.2 \sim 0.3 \mu \mathrm{g} / \mathrm{kg} /$ 分 $)$ の持続投与は継続する. (3)体位変換が必要な際には，呼気ガスのデスフルラ ン濃度が安定した時点で，体位変換を行う。

(4)体位変換終了後は，呼気ガスのデスフルラン濃度 が安定していることを確認し，低流量麻酔へ移行 する。

(5)手術中のデスフルラン濃度は $3 \%$ に固定し，手術 侵襲に応じて適宜レミフェンタニルの投与量 $(0.2$ $\sim 0.3 \mu \mathrm{g} / \mathrm{kg} /$ 分) を調節する.

(6)覚醒時の気道刺激，交感神経刺激に伴う有害事象 の予防のため，フェンタニルを手術終了 30 分前 を目安に $2 \sim 4 \mu \mathrm{g} / \mathrm{kg}$ ボーラス静注する。

(7)術後痛はアセトアミノフェンにて対応する.

8術後 X線撮影が終了, 整形外科医の確認が取れ た後に患者を仰臥位とし，この時点で新鮮ガス流 量を $6 \mathrm{~L} /$ 分とし, デスフルランの吸入を中止する. (9)呼気ガスからデスフルランが検出されなくなった 後，レミフェンタニルの持続静注を中止，スガマ デクスを用いて筋弛緩を拮抗し，患者の覚醒を待 
つて抜管する.

以上のような麻酔計画で，高齢者の大腿骨頸部骨 折手術において，デスフルランにて麻酔管理が可能 である。そして，私見であるが，覚醒直後の意識状 態, 認知機能は他の麻酔薬と比べて良いという印象 を持っている。しかしながら, 高齢者の大腿骨頸部 骨折手術においては術後長期にわたって観察してい く必要がある。

\section{IV デスフルランを用いた 小坚上腕骨骨折手術の麻酔管理}

他の揮発性吸入麻酔薬と比較した際のデスフルラ ンの小児への有効性は少ないかもしれない。そもそ も, 小児の麻酔導入では, 意識下での静脈路確保が 困難であるという理由から，揮発性吸入麻酔薬によ る緩徐導入が一般的である。そして，本邦でのデス フルランの適応が麻酔の維持であるため, 小児の麻 酔導入においてデスフルランは使用できない。とな ると, 小児の麻酔管理におけるデスフルランの有効 な場面を考えなければならないが，意義を見出すこ とは難しい。むしろ，デスフルランを用いた小児の 麻酔管理では覚醒時の気道刺激 ${ }^{10), 11)}$, 一過性の興奮 (agitation) ${ }^{12), 13)}$ などの問題があり，気管挿管下，ラ リンジアルマスクのいずれにおいても積極的にデス フルランを麻酤維持に使用する理由はない。

\section{V デスフルランを用いた 脊椎側弯症手術の麻酔管理}

小児の麻酔管理におけるデスフルランの有用性を 見出すことは難しいかもしれないが, 前述した春椎 手術におけるデスフルランの有用性を考慮すると， 成人同様に小児においても脊椎手術でのデスフルラ ンの意義はあるかもしれない。術中の MEP 記録, wake up test, 手術後の早期の神経学的評価におい て，成人同様に小児においてもデスフルランは有用 な麻酔維持薬である。

しかしながら，覚醒時の気道刺激による咳嗽，喉
頭㽷攣，分泌物元進などの可能性は成人に比して高 く $\left.{ }^{10)}, 11\right)$ ，オピオイド鎮痛薬投与などによる対応をし っかりしておかなければならない.

\section{VI デスフルランを用いた形成外科手術の麻酔管理}

本邦では一般的ではないかもしれないが，多くの 形成外科手術は日帰りで行うことができよう。日䚻 り手術に適した麻酔方法の条件は，(1)麻酔からの回 復(覚醒のみならずすべての身体的，精神的機能を 含む)が早いこと，(2)術後の副作用(特に嘔気，嘔吐 等)がないこと，(3)術後鎮痛に優れていることなど があげられる。さらに，手術が容易に施行できる環 境を提供できることも，日帰り麻酔の麻酔管理で忘 れてはならないことである。

これらのことを考慮して，日州り手術の麻酔方法 としては，回復の早い全身麻酔が好まれ，海外では 全身麻酔が一般的になっている。デスフルランは, 日帰り手術が可能な程度の形成外科手術の全身麻酔 管理に良い適応と考えられる。

デスフルランは覚醒, 認知機能の回復が早いこと はもちろんのこと ${ }^{14)}$ ，麻酔終了後の術後嘔気・嘔吐 が消失するまでの時間，集中力が回復するまでの時 間，筋肉協調運動が可能になるまでの時間等におい てセボフルランと比較して優れていたという報告 ${ }^{15)}$ もあり，日帰り手術が可能な形成外科手術に適した 麻酔薬といえよう。

ただし，日帰り手術の麻酔管理において重要な項 目である術後鎮痛に関しては，術後の嘔気・嘔吐の 発生を避けるためにも，局所浸潤あるいは区域麻酔 の併用，非ステロイド性抗炎症薬やアセトアミノフ エンの投与など, 積極的な施策を講じる必要がある.

\section{参考文献}

1) Grottke O, Dietrich PJ, Wiegels S, et al. : Intraoperative wake-up test and postoperative emergence in patients undergoing spinal surgery : a comparison of intravenous and inhaled anesthetic techniques using short-acting anesthetics. Anesth Analg 99 : 1521-1527, 
2004

2) Bilotta F, Doronzio A, Cuzzone V, et al. : Early postoperative cognitive recovery and gas exchange patterns after balanced anesthesia with sevoflurane or desflurane in overweight and obese patients undergoing craniotomy : a prospective randomized trial. J Neurosurg Anesthesiol $21: 207-213,2009$

3）平田直之：デスフルラン：脊椎手術における有用性. 日臨麻会誌 $35 ： 393-398,2015$

4) Kawaguchi M, Furuya $H$ : Intraoperative spinal cord monitoring of motor function with myogenic motor evoked potentials : a consideration in anesthesia. J Anesth $18:$ 18-28, 2004

5）佐伯茂: 術後せん妄の診断と治療, 術後精神障害. 古 家仁編. 真興交易医書出版部, 東京, 2003, 53-64

6）大井由美子, 尾本朋美, 廣加奈子ほか：高齢者大腿骨 頸部骨折手術のデスフルラン麻酔とセボフルラン麻酔 の比較検討一周術期のせん妄を中心として一. 麻酔 64 : 992-996, 2015

7) Zhang B, Tian M, Zhen Y, et al. : The effects of isoflurane and desflurane on cognitive function in humans. Anesth Analg 114 : 410-415, 2012

8) Zhang $\mathrm{Y}, \mathrm{Xu} \mathrm{Z}$, Wang $\mathrm{H}$, et al. : Anesthetics isoflurane and desflurane differently affect mitochondrial function, learning, and memory. Ann Neurol $71: 687-698$, 2012

9) Royse CF, Andrews DT, Newman SN, et al. : The influence of propofol or desflurane on postoperative cognitive dysfunction in patients undergoing coronary ar- tery bypass surgery. Anaesthesia $66:$ 455-464, 2011

10) Lerman J, Hammer GB, Verghese S, et al. : MAPS Investigators Group. Airway responses to desflurane during maintenance of anesthesia and recovery in children with laryngeal mask airways. Paediatr Anaesth $20: 495-505,2010$

11) Makkar JK, Ghai B, Bhardwaj N, et al. : Minimum alveolar concentration of desflurane with fentanyl for laryngeal mask airway removal in anesthetized children. Paediatr Anaesth 22 : 335-340, 2012

12) Davis PJ, Cohen IT, McGowan FX Jr, et al. : Recovery characteristics of desflurane versus halothane for maintenance of anesthesia in pediatric ambulatory patients. Anesthesiology $80: 298-302,1994$

13) Grundmann U, Uth M, Eichner A, et al. : Total intravenous anaesthesia with propofol and remifentanil in paediatric patients : a comparison with a desfluranenitrous oxide inhalation anaesthesia. Acta Anaesthesiol Scand $42: 845-850,1998$

14) Mahmoud NA, Rose DJ, Laurence AS, et al. : Desflurane or sevoflurane for gynaecological day-case anaesthesia with spontaneous respiration? Anaesthesia 56 : 171-174, 2001

15) Eger EI 2nd, Bowland T, Ionescu P, et al. : Recovery and kinetic characteristics of desflurane and sevoflurane in volunteers after 8 - $\mathrm{h}$ exposure, including kinetics of degradation products. Anesthesiology $87: 517-$ 526, 1997 